\title{
SOCIALIST HOUSING IN OSIJEK
}

Scientific paper / Znanstveni rad

Ivana Brkanić

(Received: 13 September 2018; accepted: 29 November 2018)

University of Osijek, Faculty of Civil Engineering and Architecture Osijek, Ph.D.

Corresponding author: ibrkanic@gfos.hr

Jelena Atanacković-Jeličić

University of Novi Sad, Faculty of Technical Sciences, Novi Sad, Ph.D., Full Professor

\begin{abstract}
Quality of an apartment is one of the basic determinants of the quality of life of its user. Modern lifestyle and housing needs have changed dramatically in recent decades as a result of various social and economic factors. The aim of the paper was to review the housing settlements, apartment buildings, and apartments constructed during the period of socialism in the City of Osijek in order to define their characteristics and provide a basis for future research on the city's housing stock quality and the possibility of its adaptation to contemporary housing needs. The research encompasses $32 \%$ of the total housing stock of the City of Osijek, or more precisely, 24 residential areas with 503 apartment buildings and 13610 apartments. As the sample contains a large number of apartments, for the purpose of easier analysis, it was categorized according to shorter time periods reflecting the housing policy periods within which the structures were built. The results show that Osijek's residential areas were built mostly within existing city blocks, and they contain freestanding or built-in elongated four-story apartment buildings. The average Osijek apartment is a "corridor apartment" with two rooms, and the average net area is $53.53 \mathrm{~m}^{2}$.
\end{abstract}

Keywords: residential areas; housing characteristics; apartment; socialist period; Osijek

\section{SOCIJALISTIČKA VIŠESTAMBENA IZGRADNJA U GRADU OSIJEKU}

Sažetak: Kvaliteta stana jedna je od osnovnih odrednica kvalitete života njegovog korisnika. Suvremeni način života i stambene potrebe uvelike su se promijenile u posljednjih nekoliko desetjeća kao posljedica različith društvenih i ekonomskih čimbenika. Cilj ovoga rada bio je dati pregled stambenih naselja, zgrada i stanova izgrađenih u socijalističkom periodu u gradu Osijeku, kako bi se definirale njihove karakteristike i stvorila baza za buduća istraživanja kvalitete stambenog fonda grada, kao i mogućnost njegove prilagodbe suvremenim stambenim potrebama. Istraživanjem je obuhvaćeno $32 \%$ ukupnog stambenog fonda grada Osijeka, točnije, 24 stambena naselja koja sadrže 503 stambene zgrade s 13610 stanova. Kako se u uzorku nalazi velik broj stanova, oni su prema vremenu izgradnje podijeljeni u kraće periode stambene politke socijalizma. Rezultati istraživanja pokazuju kako većina osječkih stambenih naselja sadrži četverokatne lamele koje su oblikovale naselje unutar već postojećih gradskih blokova. Prosječan stan u gradu Osijeku je dvosobni "koridorski" stan prosječne neto površine od 53.53 $\mathrm{m}^{2}$.

Ključne riječi: stambena naselja; karakteristike višestambene izgradnje; stan; socijalistički period; Osijek 


\section{INTRODUCTION}

The City of Osijek is the center of Osijek-Baranja County, located in the eastern part of the Republic of Croatia. According to the 2011 census report, Osijek had 83,496 inhabitants who lived in 41,955 housing units [1]. In the early and mid-20th century, Osijek was a large industrial center. Today, the main features of the city are its high unemployment rate and the deep economic crisis that has triggered the emigration trend of the predominantly younger population. After the 1991 census, Osijek recorded a steady decline in its total population.

The history of residential housing in the city of Osijek can be traced back to the beginning of the 20th century when industrial companies started to build apartment buildings for their workers [2]. Construction of three or more floors of apartment buildings with one or two apartments per floor began in the 1930s [3]. The first apartment buildings were interpolated between existing buildings. This method was practiced until the 1960s, when the construction of large residential settements began. The majority of the mult-story buildings in Osijek were built during the socialist period [4]. This data is justified by the fact that it was a long period (1945-1991), and also because within this period, the state tried to reduce the apartment deficit in the larger cities by constructing large residential settlements. The data also suggests that much of Osijek's housing stock is outdated and that it is necessary to examine its quality with respect to the modern lifestyle and new needs of its users.

This paper presents research related to the issue of residential living. In this paper, the term "housing" refers primarily to apartments within multi-story buildings. The aim of the paper is to review the housing settements, aparment buildings, and apartments constructed during the socialist period in order to define their characteristics and provide a basis for future research on the City of Osijek housing stock quality and the possibility of its adaptation to contemporary housing needs.

\section{METHODOLOGY}

For the purpose of this study, data on 178 apartment buildings projects built between 1945 and 1991 were collected from the Croatian State Archives in Osijek. Data on apartment buildings and apartments were entered in tables using Microsoft Office Excel software in order to create a research basis. For each apartment building and every apartment, the following data were provided: a) information on the apartment building, including the location, the number of occurrences of the same type of buildings in the city, year of construction, the type of construction and materials, the number of floors, entrances, and aparments, and the existence of additional spaces and b) information on the aparments within the buildings, including the number of rooms, net area of every room, and the total net area of the aparment.

Given the fact that some buildings were built several times, the study covers 13,610 apartments. As the sample contains a large number of apartments, for the purpose of easier analysis, aparments were categorized according to shorter time periods reflecting the housing policy periods within which they were built. The exact housing policy periods are shown in Table 1, and their names and characteristics are given in the following section. After this division, data analysis was performed for each period. The relevance of this study is evident in the fact that it covers about $32 \%$ of the total housing stock of the City of Osijek.

Table 1 Research sample

\begin{tabular}{|c|c|c|c|c|c|c|c|c|}
\hline \multirow{3}{*}{$\begin{array}{l}\text { Periods of Housing } \\
\text { Policy }\end{array}$} & \multicolumn{7}{|c|}{ 1945-1991 } & \multirow{3}{*}{ TOTAL: } \\
\hline & \multicolumn{2}{|c|}{ 1945-1959 } & \multicolumn{2}{|c|}{$1960-1970$} & \multicolumn{3}{|c|}{ 1971-1991 } & \\
\hline & $\begin{array}{c}1945- \\
1955\end{array}$ & $\begin{array}{c}1956- \\
1959\end{array}$ & $\begin{array}{l}1960- \\
1965\end{array}$ & $\begin{array}{l}1966- \\
1970\end{array}$ & $\begin{array}{l}1971- \\
1975\end{array}$ & $\begin{array}{l}1976- \\
1980\end{array}$ & $\begin{array}{l}1981- \\
1991\end{array}$ & \\
\hline Total number of buildings & 16 & 29 & 80 & 109 & 62 & 181 & 26 & 503 \\
\hline Total number of apartments & 192 & 425 & 2861 & 2928 & 1963 & 4272 & 969 & 13610 \\
\hline
\end{tabular}

\section{POLITICAL AND SOCIAL CONTEXT}

From 1945 to 1991, Croatia was one of the republics of the Socialist Federal Republic of Yugoslavia (SFRY). Communist policy was focused on the acceleration of industrialization while reducing the differences between urban and rural areas. As agricultural society was abolished and the country was divided into agricultural collectives, the

Brkanić, I, Atanacković-Jeličić, J 
rural population began to migrate to the cities in large numbers [5]. These events prompted an increase in the size of the urban population. Strong industrialization led to economic growth that lasted until the mid-1970s. In the 1980s, socialist policy entered a crisis, which resulted in the collapse of the SFR Yugoslavia in the early 1990s.

The development of residential housing in the SFRY and in the Socialist Republic of Croatia followed the socalled socialist or Eastern European model [6]. Under the SFRY Constitution of 1963, every resident was guaranteed the right to an aparment and until 1991 [7], the state had the responsibility for the entire housing system: its planning, construction, and allocation [8]. In an attempt to satisfy the housing needs of a large number of people, the apartments were mostly shaped according to the model: an aparment for everyone, or the so-called "protective" aparment [9]. A protective apartment is a kind of shelter, an apartment that is designed without any particular group in mind; however, in a case of emergency, it can become an apartment for anybody [10]. Despite the great efforts invested in housing construction, the whole period of socialism was marked by an apartment shortage [11].

According to Tsenkova, the era of socialist housing can be divided into three main periods: the period of the establishment of the socialist housing system, the period of revolutionary reforms, and the period of the market system [8]. The first period, lasting until 1960, was marked by massive construction of high-quality residential buildings within the existing urban tissue. Regarding the way housing stock was managed, this period can be divided into two shorter periods: the administrative budget system period (1945-1955) and the budget system period (1956-1959) [11, 12, 13].

The second period of socialism - the period of revolutionary reforms-was marked by changes in the choice of instruments used to address housing shortages. This period was marked by rational design and by the reduction of construction costs [9]. Consequently, these measures resulted in smaller apartments of lower quality [14]. The first housing reform (1960-1965) introduced the economic rules of business in housing construction and housing exchange, while the second reform (1966-1970) was characterized by the attempt to introduce the construction of apartments for the market [13].

Housing reforms created the conditions for the formation of a market housing system, but despite lofty goals, these reforms did not help to solve the housing shortage during the period from 1971 to 1975 . In the mid-1970s, an attempted solution to the housing problem was the introduction of the negotiating economy [9]. In 1976, a sociallyoriented housing construction model was established. This model was based on the construction of apartments for well-known users through self-sufficient interest communities [13]. This period of social housing is called the period of workers' self-management of housing construction and it lasted from 1976 to 1980 [15]. Despite all attempts by the socialist party to address the housing problem, the last period of socialism (1981-1991) was characterized by an increase in inflation and apartments' prices [13], as well as their constant shortage [11].

\section{CHARACTERISTICS OF SOCIALIST HOUSING IN OSIJEK}

\subsection{Residential areas}

During the period of socialism, more than 20 new residential settements were built in the City of Osijek. In this period, three approaches to urban planning were followed. As shown in Figure 1, in relation to the already built city space, new apartment buildings were built such that a) they formed a new "face" along the street by filling the unstructured edges of the existing city blocks; b) they filled the empty spaces within already existing city blocks, creating new residential areas; and c) they created new residential areas on empty urban land [14]. 



Figure 1 The way in which new housing areas were interpolated into the urban fabric

Table 2 Residential areas in Osijek 1945-1991

\begin{tabular}{|c|c|c|c|c|}
\hline \multicolumn{2}{|r|}{ Residential area } & $\begin{array}{l}\text { Construction period (according to the } \\
\text { year of obtaining a building permit) }\end{array}$ & $\begin{array}{l}\text { The position } \\
\text { in the city** }\end{array}$ & $\begin{array}{l}\text { Number of } \\
\text { buildings }\end{array}$ \\
\hline 1 & Drvljanik & $1957-1965$ & $\mathrm{C}$ & 15 \\
\hline 2 & Svačićeva-Kovačićeva street & 1958-1963 & C & 11 \\
\hline 3 & Vijenac Ivana Meštrovića & $1958-1978$ & $\mathrm{~N}$ & 56 \\
\hline 4 & Vijenac Augusta Cesarca & 1962-1964 & I & 4 \\
\hline 5 & Vijenac Paje Kolarića & 1962-1964 & i & 5 \\
\hline 6 & $\begin{array}{l}\text { Bosutsko naselje (including Dravska } \\
\text { ulica and Dragonjska ulica) }\end{array}$ & $\begin{array}{c}\text { Bosutska 1962-1964, } \\
\text { Dravska 1974, } \\
\text { Dragonjska 1975-1989 }\end{array}$ & $\mathrm{N}$ & 16 \\
\hline 7 & Vijenac Jakova Gotovca & $1964-1966$ & I & 5 \\
\hline 8 & Naselje Stanka Vraza & $1965-1968$ & I & 7 \\
\hline 9 & Vijenac Ljube Babića & 1966 & I & 5 \\
\hline 10 & Blok Centar & $1966-1969$ & I & 6 \\
\hline 11 & Jug II & $1966-1986$ & $\mathrm{~N}$ & 102 \\
\hline 12 & Vijenac Josipa Kozarca & 1967 & I & 18 \\
\hline 13 & Sjenjak & 1970-1988 & $\mathrm{N}$ & 40 \\
\hline 14 & Drinska (Umirovljeničko naselje) & $1971-1980$ & $\mathrm{~N}$ & 13 \\
\hline 15 & Ljudevita Posavskog & 1973-1977 & C & 34 \\
\hline 16 & Vijenac Ivana Česmičkog & 1975 & $\mathrm{~N}$ & 14 \\
\hline 17 & Vijenac Murse* & 1977 & I & 4 \\
\hline 18 & Vijenac Gorana Zobundžije & 1978 & I & 16 \\
\hline 19 & Vijenac Petrove gore & $1978-1980$ & $\mathrm{~N}$ & 14 \\
\hline 20 & Naselje Vladimira Nazora & 1979 & I & 21 \\
\hline 21 & Vijenac Kraljeve Sutjeske & 1980 & I & 11 \\
\hline 22 & Gornjodravska obala & $1980-1988$ & $\mathrm{~N}$ & 18 \\
\hline 23 & Vijenac Slavka Kolara & 1982 & I & 6 \\
\hline 24 & Vijenac Dinare & $1987-1989$ & $\mathrm{~N}$ & 11 \\
\hline \multicolumn{4}{|c|}{$\begin{array}{l}\text { * the total number of buildings did notinclude buildings that closed the block towards Vukovarska ulica and } \\
\text { Hutlerova ulica and Trg Bana Josipa Jelačića }\end{array}$} & TOTAL: \\
\hline \multicolumn{4}{|c|}{$\begin{array}{l}{ }^{* *} \mathrm{C} \text { - block closure; I- residential area inside the block; } \\
\mathrm{N} \text { - new residential area }\end{array}$} & 452 \\
\hline
\end{tabular}

Table 2 shows the residential areas built in Osijek in the socialist period, as well as information on the period of their construction, the way in which they were incorporated into the existing urban fabric, and the number of apartment buildings catalogued by this study in each settement. The map that follows (Figure 2) shows the locations of these residential areas in the City of Osijek. Of the 503 apartment buildings in the sample, $452(89.9 \%)$ are located in one of the listed residential areas. 


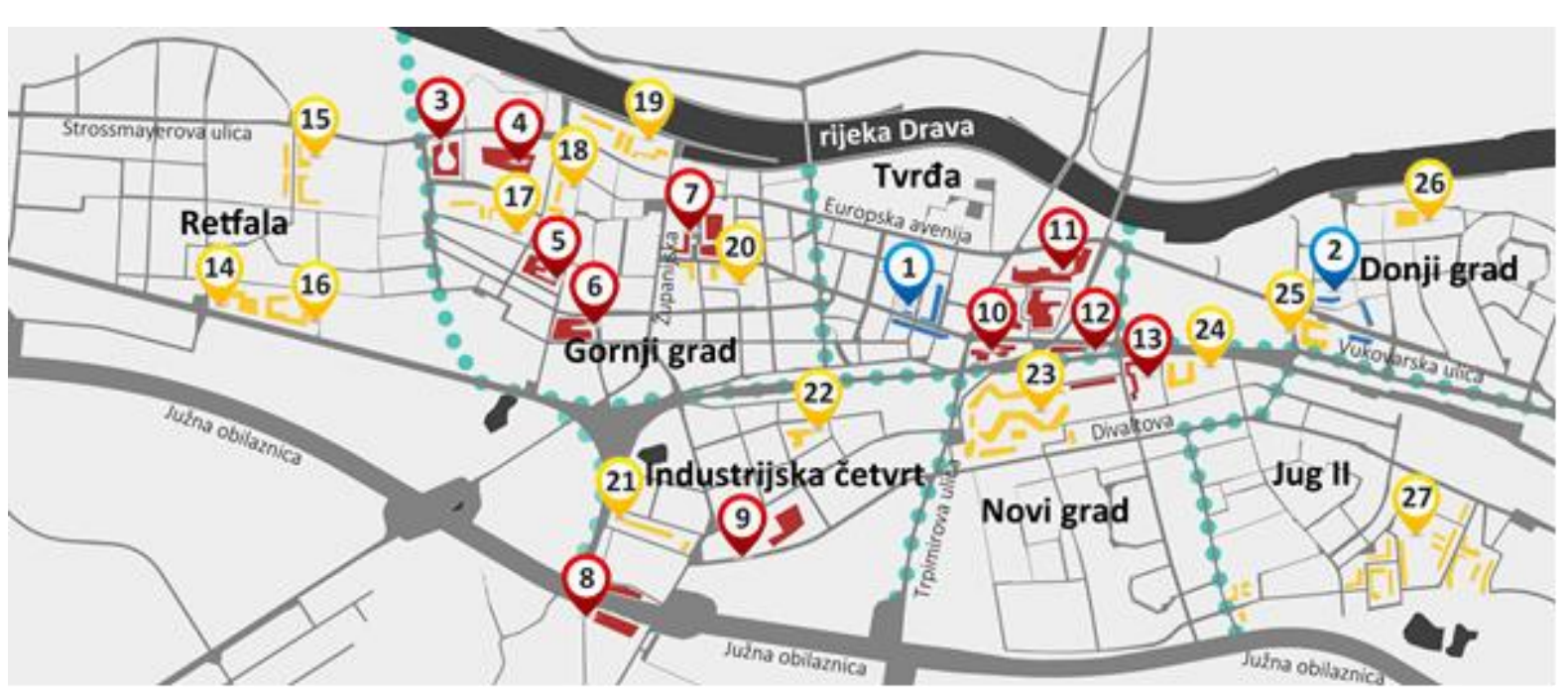

BLUE: (1945.-1959.): 1 Vukovarska ulica (west), 2 Trg bana Josipa Jelačića (Donji grad); RED: (1960.-1970.): 3 Vijenac Josipa Kozarca, 4 Vijenac Augusta Cesarca, 5 Vijenac Ljube Babića, 6 Naselje Stanka Vraza, 7 Blok centar, 8 Dragonjska i Dravska ulica, 9 Drinska ulica (Umirovjeničko naselje), 10 Drvljanik, 11 Vijenac Ivana Meštrovića, 12 Vukovarska ulica (east), 13 Svačićeva ulica i Ulica Ivana Gorana Kovačića; YELLOW (1971.-1991.): 14 Vijenac Dinare, 15 Ulica Ljudevita Posavskog, 16 Vijenac Petrove gore, 17 Naselje Vadimira Nazora, 18 Vijenac Gorana Zobundžje, 19 Gornjodravska obala, 20 Blok centar II, 21 Bosutsko naselje, 22 Vijenac Kraljeve Sutjeske, 23 Sjenjak, 24 Vijenac Ivana Česmičkog, 25 Vijenac Murse, 26 Vijenac Slavka Kolara, 27 Jug II

\subsection{Apartment buildings}

Figure 2 Locations of residential areas

The massive construction of apartment buildings in the socialist period was enabled by the modernization of the construction industry, partial prefabrication, and the construction of typical buildings. Analysis of residential settements and apartment buildings revealed that some apartment buildings were constructed several times. Their repeition within the city took place in one of the three following ways: a) the construction of a typical building in several locations throughout the city; b) the construction of an entire residential area on the basis of one typical building, examples of which are residential areas Vijenac Josipa Kozarca and Vijenac Ivana Česmičkog; and c) the construction of some residential areas based on three or four typical buildings, examples of which are residential areas Ulica Ljudevita Posavska, Naselje Vladimira Nazora, and Jug II.

Most often, apartment buildings were built as freestanding or built-in elongated lower-height buildings. There are a small number of skyscrapers (Figure 3a and $b$ ). The analyzed buildings contain 1-14 floors in addition to the ground floor, and the vast majority of them have one underground floor. Most apartment buildings are four-story buildings. Observed buildings contain between 2 and 145 apartments, but most of them have between 20 and 30 apartments. More than $30 \%$ of the apartment buildings have three apartments per floor, $20 \%$ have two apartments per floor, and $20 \%$ have four apartments per floor.

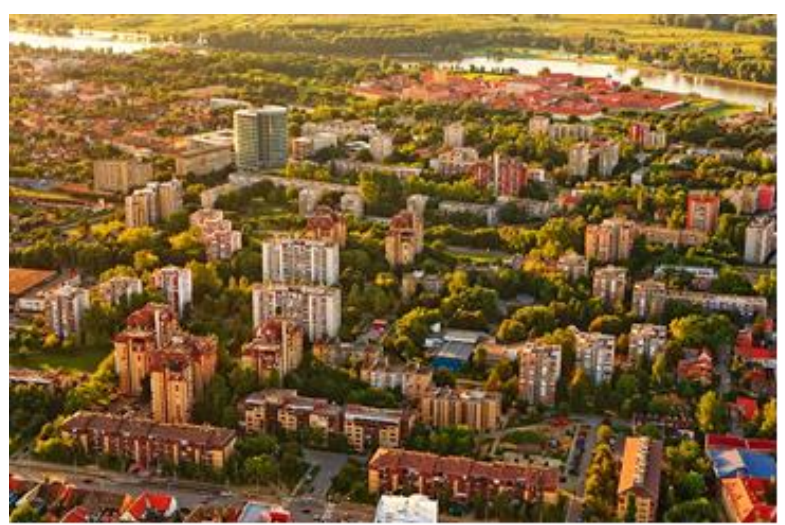

a)

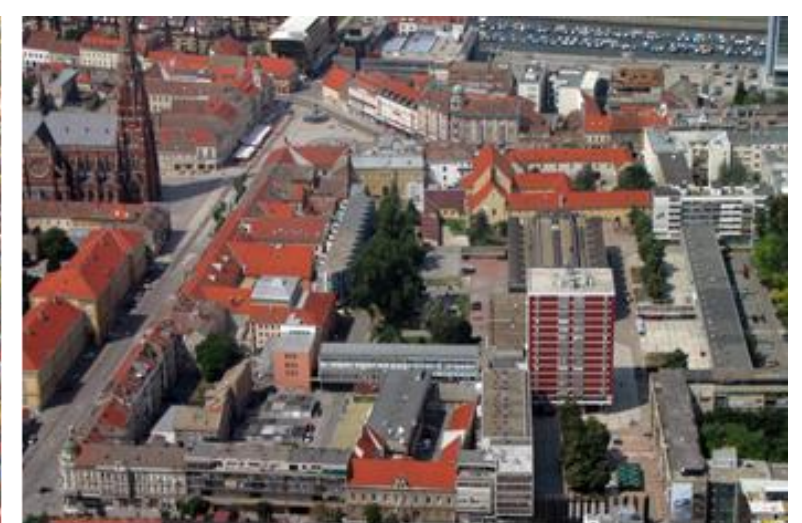

b)

Figure 3 Areal view of a) Sjenjak, Drvljanik, and Vijenac Ivana Meštrovića [16] and b) Blok center [17]

Brkanić, I, Atanacković-Jeličić, J

htps://doi.org/10.13167/2018.17.1 
Most often, the load-bearing structure of the apartment buildings is reinforced concrete walls and ceiling panels, as well as brick walls with vertical and horizontal reinforcements and reinforced concrete or semiprefabricated ceiling panels. There are also several buildings with a skeletal construction system, as well as buildings that are prefabricated according to the principles of IMS-Žeželj [18]. The roof of residential buildings is usually a straight reinforced concrete slab, but mansard roof buildings, as well as those with traditional wooden roof structures, have been constructed in smaller numbers.

Apartment buildings from the socialist period are also characterized by the existence of common spaces such as laundry rooms, bicycle and baby carriage storage areas, home counseling facilities, roof terraces, and war shelters.

\subsection{Apartments}

In the socialist period, the apartment became a set of basic, minimum-sized rooms that were arranged around a central corridor [3]. The residential and service areas that existed in large aparments of the prewar period were transformed into just one room. From the service zones of aparments built before 1945, only kitchens with small storage areas or ventilated closets remain. Large residential areas of pre-war aparments were replaced with living rooms and bedrooms of minimal dimensions. In the sample, there are a small number of aparments that have more than two bedrooms, and most apartments have an outdoor area. Table 3 shows the apartments in the sample according to their size (room number). The living room is always counted as one of the rooms, and 0.5 stands for a half room, such as a bedroom for one person. For example, a 2.5 room apartment consists of a living room, a bedroom, and a half room. The size of individual rooms in the apartment, as well as the average net area of the apartments built in the shorter periods of socialist housing policy, are shown in Table 4. Table 5 gives an overview of the same data for the whole socialist period.

Table 3 Apartment sizes

\begin{tabular}{|c|c|c|c|c|c|c|c|c|c|c|c|}
\hline $\begin{array}{l}\text { Number of } \\
\text { rooms: }\end{array}$ & \multirow{2}{*}{$S$} & \multirow{2}{*}{1} & \multirow{2}{*}{1.5} & \multirow{2}{*}{2} & \multirow{2}{*}{2.5} & \multirow{2}{*}{3} & \multirow{2}{*}{3.5} & \multirow{2}{*}{4} & \multirow{2}{*}{4.5} & \multirow{2}{*}{5} & \multirow{2}{*}{ TOTAL: } \\
\hline $\begin{array}{l}\text { Construction } \\
\text { period: }\end{array}$ & & & & & & & & & & & \\
\hline $1945-1955$ & 2 & 79 & 4 & 78 & 9 & 18 & 0 & 0 & 2 & 0 & 192 \\
\hline 1956-1959 & 47 & 69 & 22 & 242 & 15 & 22 & 8 & 0 & 0 & 0 & 425 \\
\hline $1960-1965$ & 58 & 597 & 21 & 1486 & 358 & 336 & 3 & 2 & 0 & 0 & 2861 \\
\hline $1966-1970$ & 206 & 840 & 13 & 1228 & 117 & 420 & 100 & 0 & 0 & 4 & 2928 \\
\hline $1971-1975$ & 355 & 495 & 190 & 657 & 166 & 98 & 0 & 2 & 0 & 0 & 1963 \\
\hline $1976-1980$ & 253 & 993 & 292 & 1278 & 986 & 400 & 49 & 14 & 3 & 4 & 4272 \\
\hline $1981-1991$ & 45 & 281 & 46 & 381 & 60 & 142 & 13 & 0 & 0 & 1 & 969 \\
\hline TOTAL: & 966 & 3354 & 588 & 5350 & 1711 & 1436 & 173 & 18 & 5 & 9 & 13610 \\
\hline
\end{tabular}

Table 4 The average size of rooms and apartments for shorter periods of socialist housing policy

\begin{tabular}{c|cccccccccc}
\hline $\begin{array}{c}\text { Construction } \\
\text { period }\end{array}$ & $\begin{array}{c}\text { Indoor area } \\
\text { Entrance } \\
\text { area } \\
\mathrm{m}^{2}\end{array}$ & $\begin{array}{c}\text { Bathroom } \\
\mathrm{m}^{2}\end{array}$ & $\begin{array}{c}\text { WC } \\
\mathrm{m}^{2}\end{array}$ & $\begin{array}{c}\text { Kitchen } \\
\mathrm{m}^{2}\end{array}$ & $\begin{array}{c}\text { Living } \\
\text { room } \\
\mathrm{m}^{2}\end{array}$ & $\begin{array}{c}\text { Dining } \\
\text { room } \\
\mathrm{m}^{2}\end{array}$ & $\begin{array}{c}\text { Bedroom } \\
\mathrm{m}^{2}\end{array}$ & $\begin{array}{c}\text { Loggia } \\
\mathrm{m}^{2}\end{array}$ & $\begin{array}{c}\text { Balcony } \\
\mathrm{m}^{2}\end{array}$ & $\begin{array}{c}\begin{array}{c}\text { TOTAL } \\
\text { AREA }\end{array} \\
\text { m }^{2}\end{array}$ \\
\hline $1945-1955$ & 5.57 & 5.19 & 1.42 & 10.13 & 19.72 & - & 16.95 & 4.58 & 5.20 & 61.96 \\
$1956-1959$ & 4.57 & 3.79 & 1.45 & 8.84 & 18.96 & - & 13.96 & 5.70 & 4.39 & 52.11 \\
$1960-1965$ & 4.56 & 3.24 & 1.24 & 8.53 & 17.61 & 3.89 & 12.75 & 4.62 & 3.15 & 50.64 \\
$1966-1970$ & 5.65 & 3.34 & 1.34 & 8.14 & 17.58 & 7.55 & 13.01 & 4.58 & 3.16 & 52.54 \\
$1971-1975$ & 4.75 & 3.69 & 1.41 & 7.68 & 17.24 & 3.96 & 11.55 & 2.82 & 4.14 & 45.60 \\
$1976-1980$ & 5.11 & 4.10 & 1.66 & 6.88 & 18.63 & 6.39 & 13.31 & 5.63 & 5.45 & 58.16 \\
$1981-1991$ & 6.36 & 4.47 & 1.99 & 8.46 & 18.63 & 8.22 & 11.50 & 5.54 & 3.79 & 59.42 \\
\hline
\end{tabular}

Brkanić, l, Atanacković-Jeličić, J 
Table 5 The average size of rooms and apartments for the socialist period

\begin{tabular}{|c|c|c|c|c|c|c|c|c|c|c|}
\hline \multirow[b]{2}{*}{$\begin{array}{c}\text { Construction } \\
\text { period }\end{array}$} & \multicolumn{7}{|c|}{ Indoor area } & \multicolumn{2}{|c|}{ Outdoor area } & \multirow[b]{2}{*}{$\begin{array}{l}\text { TOTAL } \\
\text { NET } \\
\text { AREA m² }\end{array}$} \\
\hline & $\begin{array}{c}\text { Entrance } \\
\text { area } \\
\mathrm{m}^{2}\end{array}$ & $\begin{array}{c}\text { Bathroom } \\
\mathrm{m}^{2}\end{array}$ & $\begin{array}{l}\text { WC } \\
m^{2}\end{array}$ & $\begin{array}{c}\text { Kitchen } \\
\mathrm{m}^{2}\end{array}$ & $\begin{array}{c}\text { Living } \\
\text { room } \\
\mathrm{m}^{2}\end{array}$ & $\begin{array}{c}\text { Dining } \\
\text { room } \\
\mathrm{m}^{2}\end{array}$ & $\begin{array}{c}\text { Bedroom } \\
\mathrm{m}^{2}\end{array}$ & $\begin{array}{c}\text { Loggia } \\
\mathrm{m}^{2}\end{array}$ & $\begin{array}{c}\text { Balcony } \\
\mathrm{m}^{2}\end{array}$ & \\
\hline 1945-1991 & 5.14 & 3.73 & 1.49 & 7.83 & 18.02 & 6.53 & 12.84 & 4.95 & 3.68 & 53.53 \\
\hline
\end{tabular}

Typical spatial organization of an apartment from the period of socialism is as a "corridor apartment" [3]. The central part of this type of apartment is the hallway, to which all rooms are connected. Most often, these apartments have a kitchen with a ventilated closet or storage room, a bathroom, a living room, and one or two bedrooms. Outdoor spaces, loggias, or balconies are most often connected to the living room or kitchen, and in a smaller number of cases to the bedroom. At the beginning of the 1960s, the corridor apartment was enriched by the circular connection between the entrance hall, the kitchen, and the living room. Often, this connector includes a dining area. The orientations of corridor dwellings can be one- or two-sided, and these layouts exist in about equal numbers. The apartment layout in Figure 4a presents the spatial organization of the most-constructed apartment in the City of Osijek. It is a two-room, $59.67 \mathrm{~m}^{2}$, corridor apartment built in the 1970s, and it occurs about 130 times in the Ulica Ljudevita Posavskog, about 400 times in Jug II, and about 110 times in Ulica Vladimira Nazora.

During the last ten years of socialism, as a result of the market sales of apartments, there was an increase in the net area of apartments, and a new type of apartment, the "duplex aparment," appeared [3]. This aparment is characterized by the division of the daytime part and the nightime part according to apartment floors. The lower floor of the apartment is intended for the common use of all its tenants and contains a living room, dining room, kitchen with the storage area, and a separate toilet, while the upper floor contains private rooms such as bedrooms, wardrobes, and bathrooms. The layout of such apartment is shown in Figure $4 \mathrm{~b}$; it is a three-room aparment built in the 1980s in Vijenac Dinare.



$\begin{array}{llllll}0 & 1 & 2 & 3 & 4 & 5 m\end{array}$

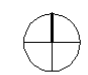

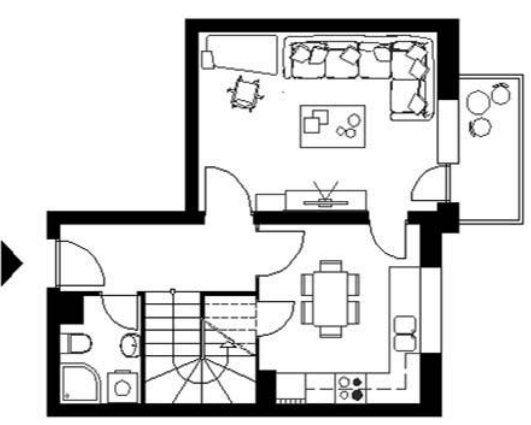

$0 \quad 1 \quad 2 \quad 3 \quad 4 \quad 5 m$
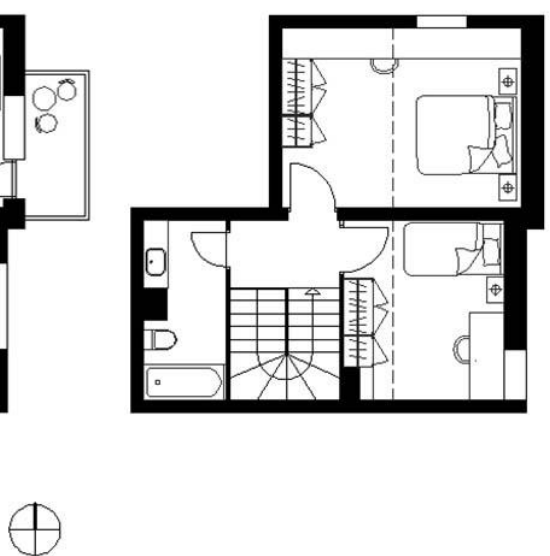

Figure 4 Apartments layouts: a) Most common "corridor apartment," b) Typical "duplex"

Small apartments (studios, one-room and one and a half room) within this period are represented in large numbers. Within these apartments, the rooms are also arranged around the central corridor. The basic areas of these apartments are the entrance hall, living room, kitchen area, and bathroom, and in a small number of apartments, there is a half room (a bedroom for one person). In a large number of small apartments from this period, there is an outdoor space in the form of a loggia or a balcony which is accessed from the kitchen or living room. The smallest apartment in the sample is a studio apartment measuring $19.29 \mathrm{~m}^{2}$, which is located in Vukovarska ulica (Figure 5). The building in which the apartment is located was granted a building permit in 1970.

Brkanić, I, Atanacković-Jeličić, J 


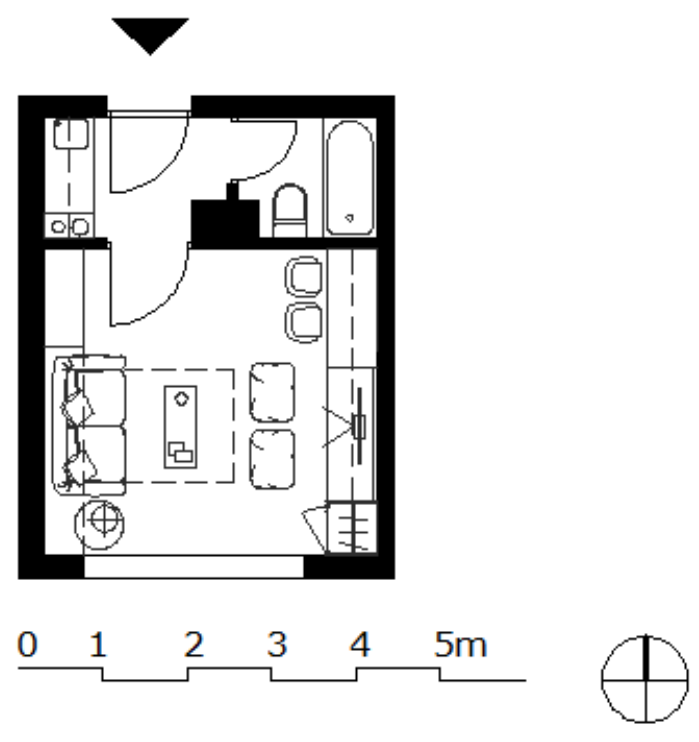

Figure 5 Layout of the smallest apartment in the sample

\section{DISCUSSION}

In the period from 1945 to 1991, 24 residential areas were built in the City of Osijek. Half of the residential areas $(\mathrm{N}=12)$ were built within an already existing city block, $9(37.5 \%)$ were built on empty urban land, while the remaining three (12.5\%) filled the edges of the existing blocks. The largest number of residential areas originated from the period of the market system (1971-1991). Out of the 503 aparment buildings in the sample, only 51 $(10.1 \%)$ of them are not found inside residential areas but are located within city streets. This kind of spatial planning was enabled by the existence of already-formed city blocks, which, due to their large area and low population density, left room for the construction of residential settements within their boundaries.

Based on the number of rooms in the apartments built during the period of establishment of the socialist housing system (1945-1959), we can see that the construction of two-room apartments (52\%) predominates and that approximately $32 \%$ of the apartments are studio and one-room aparments. Large apartments are represented in very small numbers. The second period of socialist housing construction (the period of revolutionary reforms, 1960-1970) brought an increase in the number of apartments, but the standard of apartments does not increase in favor of those with more rooms. Smaller dwellings still prevail. More than $70 \%$ of the apartments have one to two bedrooms, while almost $30 \%$ of them are studios and one or one-and-a-half room apartments. Unlike the previous period, the number of apartments with three or more rooms increased to approximately $13 \%$ of all aparments in this period. More than 7,200 apartments were built during the market housing system (1971-1991). In this period, most of the apartments built, approximately $48 \%$, were two-room and two-and-a-half room apartments. The next largest quantity were small apartments (studios, one-room, and one-and-a-half room). Within the last period of socialist housing construction (1971-1991), 10\% of apartments built had three or more rooms.

Within the context of shorter periods of socialist housing policy, the largest number of apartments (31.4\%) were built in the period of the workers' self-management of housing construction (1976-1980). The largest number of studio apartments were built from 1971 to 1975 , while the largest number of three-room apartments were built in period from 1966 to 1970. The sample contains only $205(1.5 \%)$ apartments with more than three rooms. If we look at the period of socialist housing as a whole, we can see that the largest number, approximately $40 \%$ of all apartments built, is of two-room apartments. Overall, most apartments (52\%) are medium-sized (two and two-anda-half room apartments), while small apartments (studio, one room, and one-and-a-half room) represent $36 \%$ of the sample. From these data, we can see that the Osijek housing stock from this period is characterized by smaller apartments which, on average, contain a living room and a bedroom. The large representation of small apartments is the result of a housing policy that had imposed regulations that prescribed the economical and rational construction of apartment buildings. For these same reasons, throughout the whole period of socialism, the living room was considered to be a sleeping room for two people. Thus, for example, a two-bedroom apartment was Brkanić, l, Atanacković-Jeličić, J 
assigned to four-member families. This type of aparment organization provided housing for a large number of people.

During the socialist era, the average floor area of apartments was $53.53 \mathrm{~m}^{2}$. As this era covers a period of more than 40 years, there are significant differences between the characteristics of apartments within certain periods. The largest average net area of apartments was recorded for the period of establishing the socialist housing system, especially in its first period from 1945 to 1955 when the average area was $61.96 \mathrm{~m}^{2}$. The lowest average net area of apartments was recorded during the period of the market housing system between 1971 and 1975, when it was only $45.60 \mathrm{~m}^{2}$.

The average living room area in the socialist period was $18.02 \mathrm{~m}^{2}$, the kitchen area was $7.83 \mathrm{~m}^{2}$, and the bedroom area was $12.84 \mathrm{~m}^{2}$. The largest average areas of living rooms, kitchens, and bedrooms were in apartments built in the first period (1945-1955), after which they gradually began to fall. It is interesting to observe the changes in apartment sizes through the periods. The lowest living room net area was recorded in the period from 1971 to 1975, when it was $17.24 \mathrm{~m}^{2}$, after which it began to grow again but did not go above the average area at the beginning of socialism. The same happened to the net area of kitchens, which recorded a steady decline until 1980 . It only increased in the last period, when it was $8.46 \mathrm{~m}^{2}$, but was still more than $16 \%$ smaller than kitchens built at the beginning of the socialist period. Bedroom size has had the most significant differences between periods, with the biggest leaps in the net area. The minimum dimension of bedrooms was recorded in the period from 1971 to 1975 and from 1981 to 1991, when it was around $11.5 \mathrm{~m}^{2}$. Fluctuations in net areas of outdoor spaces are also visible throughout the whole socialist period. The lowest floor area of loggias was recorded in the period from 1971 to 1975 , when it was $2.82 \mathrm{~m}^{2}$. The net areas of bathrooms, toilets, and balconies were the lowest in the period from 1960 to 1970, which corresponds to the period of housing reform, when the design process was characterized by a reduction in construction costs and rational management of space. It is interesting to note that the dining room as a separate aparment area appears from 1960-1965 onwards. Its net area was only $3.89 \mathrm{~m}^{2}$ in that period but rose to $8.22 \mathrm{~m}^{2}$ in the period from 1981 to 1991.

The larger areas of residential spaces, as well as the total net area of apartments at the beginning of socialism era, were an attempt to keep the dimensions which, though slightly smaller, were common in the prewar period. In later periods, smaller dimensions of living rooms, bedrooms, and kitchens were the result of a different approach to housing policy, as well as the rationalization of the design process and construction of apartment buildings. The application of rationalization measures is most noticeable in apartments built in the period following the implementation of housing reforms (1971-1975), when the smallest average dimensions of certain rooms and apartments were recorded.

\section{CONCLUSION}

This research encompasses $32 \%$ of the total housing stock of the City of Osijek, or more precisely, 24 residential areas with 503 apartment buildings and 13,610 apartments. The observed residential areas were built mostly within existing city blocks, and they contain freestanding or built-in elongated four-story apartment buildings with 20 to 30 apartments. The sample consists of mostly two-room apartments (39.3\%), followed by one-room (24.6\%) and threeroom (10.6\%) apartments. The studios make up about $7 \%$ of the sample, and only $1.5 \%$ of aparments have more than three rooms.

The largest number of apartments were designed as "corridor" apartments and contain an entrance area, a kitchen, a bathroom, a living room, one bedroom, and an outdoor space (loggia or balcony). During the socialist era, the average floor area of apartments was $53.53 \mathrm{~m}^{2}$, the average living room in the social period was $18.02 \mathrm{~m}^{2}$, the kitchen was $7.83 \mathrm{~m}^{2}$, and the bedroom was $12.84 \mathrm{~m}^{2}$.

Modern lifestyle and housing needs have changed dramatically in recent decades as a result of various social and economic factors. Research results indicate that a large part of Osijek's housing stock is outdated and is mostly made of small aparments divided into even smaller rooms. It is of great importance to find the way in which such housing stock can respond to future housing needs.

Data from this research will be useful in future research on the quality of Osijek's housing stock and the possibility of its adaptation to contemporary housing needs. 


\section{References}

[1] Central Bureau of Statistics: Statistical reports of different years, www.dzs.hr, Accessed: 25 September 2017

[2] Radović-Mahečić, D. 2006: Osječka arhitektura između dva svjetska rata u kontekstu hrvatske moderne arhitekture, in: J. Martinčić, i D. Hackenberger, eds., 2006. Osječka arhitektura: 1918.-1945. Osijek: Hrvatska akademija znanosti i umjetnosti i Zavod za znanstveni i umjetnički rad u Osijeku, pp.21-34

[3] Brkanić, I.; Stober, D.; Mihić, M. 2018: A Comparative Analysis of the Spatial Configuration of Apartments Built in Osijek, Croatia between 1930 and 2015, Journal of Asian Architecture and Building Engineering, 17 (1), pp.23-30

[4] Bežovan, G.; Dakić, S. 1990: Alternativna stambena politika, Radničke novine, Zagreb

[5] Damjanović, D. 2006: Stambena arhitektura dvadeseth godina 20. stoljeća u Osijeku. in: Martinčić J.; Hackenberger D., eds., 2006: Osječka arhitektura: 1918.-1945. Osijek: Hrvatska akademija znanosti i umjetnosti i Zavod za znanstveni i umjetnički rad u Osijeku, pp.75-122

[6] Petrovic-Grozdanovic, N. et al. 2017: The spatial comfort of social housing units in the post-socialist period in Serbia in relation to the applicable architectural norms, Cities, 62, pp.88-95, https://doi.org/10.1016/i.cities.2016.12.014

[7] Ustav SFRJ, Službeni list SFRJ, 14/ 1963

[8] Tsenkova, S. 2009: Housing Policy Reforms in Post-Socialist Europe: Lost in Translation. Heidelberg: Physica-Verlag.

[9] Vezilić Strmo, N.; Delić, A.; Kincl, B. 2013: Uzroci problema postojećeg stambenog fonda u Hrvatskoj, Prostor, 21 (2), pp.340-349

[10] Rogić, I., 1987: Obilježja urbanizacijskog procesa i takozvano stambeno pitanje, in: Stambena politka i stambene potrebe, knjiga 1. Biblioteka Iskustva, Zagreb, pp.15-25

[11] Bežovan, G. 1987: Stanovanje i stambena kriza, CDD, Zagreb

[12] Mrčela, V. 1982: Neki aspekti odnosa ponuda i potražnje u stanogradnji Jugoslavije od 1945. do danas, Čovjek i prostor, 344, pp.13-15

[13] Jelinić, G. 1994: Kako riješit stambenu krizu, AGM, Zagreb

[14] Brkanić, I. 2018: Model korisničkog vrednovanja prostornih karakteristika stana, PhD. Univerzitet u Novom Sadu

[15] Mandič, S. 1994: Socijalno stanovanje u Sloveniji: Institucija na marginama tranzicijskih procesa, Društvena istraživanja, 1 (3), pp. 35-53

[16] www.osijek031.com, Acessed 5 July 2016

[17] www.sib.hr, Acessed 5 July 2016

[18] Knežević, G.; Kordiš, I. 1981: Stambene i javne zgrade, Tehnička knjiga, Zagreb

Please cite this article as:

Brkanić, I.; Atanacković-Jelčić, J.: Socialist housing in Osijek, Electronic Journal of the Faculty of Civil Engineering Osijek-e-GFOS, 2018, 17, pp. 1-10, https://doi.org/10.13167/2018.17.1 